\title{
Petal and Sepal Epidermal Micromorphology of Six Lathyrus Taxa (Fabaceae) and their Systematic Value
}

\author{
Hüseyin ÇİLDİR ${ }^{1}$, Ahmet KAHRAMAN²${ }^{2}$ Musa DOĞAN ${ }^{1}$ \\ ${ }^{1}$ Middle East Technical University, Faculty of Arts and Sciences, Department of Biological Sciences, 06531 Ankara, Turkey; childir@gmail.com \\ ${ }^{2} U_{\S ̧}$ ak University, Faculty of Arts and Sciences, Department of Biology, $64200 U_{\xi ̧}$ ak, Turkey; kahramanahmet64@gmail.com
}

\begin{abstract}
In this study, the epidermal types and their distribution on dorsal and lateral petals, the trichome types and their density on sepals of Lathyrus chloranthus, L. digitatus, L. laxiflorus subsp. laxiflorus, L. roseus subsp. roseus, L. sativus, and L. tuberosus, belonging to sections Lathyrus, Lathyrostylis, Pratensis, and Orobon of the genus Lathyrus in Turkey were investigated using light microscopy (LM) and scanning electron microscopy (SEM), and the systematic significance of these characters was evaluated. These taxa, except $L$. sativus, are studied for the first time under aspects of the petal and sepal micromorphology. Three major epidermal types were recognized on the petal: tabular rugose striate cells (TRS), areolate cells with more or less striations (AS), and papillose conical striate cells (PCS). TRS and AS were further subdivided into three subtypes. TRS was found on the dorsal and lateral petals of L. chloranthus, L. sativus, and $L$. tuberosus: the dorsal petals of $L$. roseus subsp. roseus and the lateral petals of $L$. laxiflorus subsp. laxiflorus, while AS was present on the dorsal and lateral petals of $L$. digitatus and the lateral petals of $L$. roseus subsp. roseus. PCS was found only on the dorsal petals of $L$. digitatus. Three main types of trichomes on the sepal were observed: peltate glandular, capitate glandular, and nonglandular trichomes. The capitate glandular and nonglandular trichomes were further subdivided into three subtypes. The peltate glandular trichomes were present only in $L$. chloranthus, but absent in the others. The capitate glandular trichomes were found in $L$. chloranthus, L. laxiflorus subsp. laxiflorus, L. roseus subsp. roseus, and L. tuberosus. The nonglandular trichomes were always present in L. chloranthus and L. laxiflorus subsp. laxiflorus. The present results show that the petal and sepal micromorphology can be used in delimitation of the taxa based on petal and sepal micromorphology.
\end{abstract}

Keywords: Fabaceae, Lathyrus, micromorphology, petal, sepal, Turkey

\section{Introduction}

Lathyrus L. (Fabaceae) is the largest genus in the economically important tribe Fabeae of the subfamily Papilionoideae, with approximately 170 species worldwide (ILDIS, 2010; Lewis et al., 2005). The eastern Mediterranean region is the main center of diversity for the genus, which is less diversified in North and South America (Kupicha, 1983). Many species of the genus are found throughout the temperate northern hemisphere (Asmussen and Liston, 1998; Kupicha, 1983). Moreover, a few species are distributed in the tropical zones and the highlands of East Africa (Davis, 1970; Kenicer et al., 2005; Senn, 1938). Lathyrus species are economically important as food and fodder crops, ornamentals, soil nitrifiers, dune stabilizers, significant agricultural weeds, and model organisms for genetic and ecological research (Chittenden, 1951; Kenicer et al., 2005).

Most researchers separate Lathyrus into 12 or $13 \mathrm{sec}$ tions (Asmussen and Liston, 1998; Czefranova, 1971; ILDIS, 2002; Kupicha, 1983; Leht, 2009). Kupicha’s (1983) infrageneric classification is the only worldwide treatment of the genus. She divided it into 13 sections based on morphological traits: Orobus, Lathyrostylis,
Lathyrus, Orobon, Pratensis, Aphaca, Clymenum, Orobastrum, Viciopsis, Linearicarpus, Nissolia, Neurolobus and Notolathyrus. Since Kupicha’s (1983) monograph, Doğan et al. (1992) have carried out a phenetic analysis of 54 Lathyrus species in Turkey and clustered them into 9 sections. Most recent molecular phylogenetic studies (Croft et al., 1999; Kenicer et al., 2005) generally support Kupicha's (1983) classification.

In Turkey, the genus is represented by 76 taxa $(66$ species) (Davis, 1970; Davis et al., 1988; Güneş and Özhatay, 2000; Genç and Şahin, 2011) belonging to 11 sections according to the infrageneric system of Kupicha (1983). These sections are Orobus, Lathyrostylis (Platystylis), Lathyrus (syn. Cicercula), Orobon, Pratensis, Aphaca, Clymenum, Orobastrum, Viciopsis, Linearicarpus, and Nissolia (Kupicha, 1983). Turkey is a major center of diversity for the genus in Eurasia with a high number of species.

The epidermal surface of petals is significant in pollination because it affects the way that pollinators perceive and interact with the flower (Ojeda et al., 2009). Many legume species have a specialized flower morphology that promotes pollinator specificity (Ojeda et al., 2009). In Compositae (Baagoe, 1977, 1980; Hansen, 1991) and Fabaceae 
36

(Stirton, 1981) the properties of the petal epidermal types have been used for taxonomic and phylogenetic analyses.

Studies on the petal and sepal epidermal micromorphology of leguminous species are rather limited (Christensen and Hansen, 1998; Hammett et al., 1994; Ojeda et al., 2009; Stirton, 1981). Stirton (1981) examined the lateral petals of the papilionoids. Hammett et al. (1994) reported the epidermal type of the dorsal and lateral petals in 2 Lathyrus species, and Ojeda et al. (2009) reported the epidermal types on the dorsal, lateral, and ventral petals of 7 species of the same genus. Except for L. sativus, the petal, and sepal micromorphology of $L$. chloranthus, $L$. digitatus, $L$. laxiflorus subsp. laxiflorus, $L$. roseus subsp. roseus, and $L$. tuberosus have not been analyzed previously. Therefore, this study aims to investigate the epidermal types and their distribution on dorsal, and lateral petals and the trichome types and their density on sepals of these six taxa from four sections, namely Lathyrus, Lathyrostylis, Pratensis, and Orobon distributed in Turkey, and to evaluate the systematic value of these characters.

\section{Material and methods}

Specimens of the six Lathyrus taxa studied were collected from their natural habitats in Central Anatolia, Turkey. The collected specimens were deposited in the herbarium of Department of Biological Sciences, Middle

Tab. 1. Collection data of the Lathyrus specimens examined
East Technical University (METU), Ankara. The voucher specimens are listed in Tab. 1.

Petals and sepals of fully opened flowers were investigated using a Leica DM1000 LM and a QUANTA 400F SEM. After a number of specimens had been compared under LM, three to six petals and sepals were examined for each species under SEM. Two kinds of petals (a dorsal petal, called a 'standard' and two lateral petals or 'wings') were examined. The epidermal types of the petals were classified based on cell size, shape (the primary sculpture), and on the fine relief of the cell wall, using the terminology of Barthlott (1977) and Kay et al. (1981). To investigate trichomes on the sepals, sections were made by hand using commercial razor blades. The trichome types and densities are described. The general trichome terminology follows Metcalfe and Chalk (1957) and Kahraman et al. (2010).

\section{Results}

\section{Petal micromorphology}

In the Lathyrus taxa studied, three main epidermal cell types were determined: tabular rugose striate cells (type 1 ), areolate cells with more or less striations (type 2) and papillose conical striate cells (type 3) (Fig. 1-16, Tab. 2).

Type 1. Tabular rugose striate cells (TRS): This type was further subdivided into three subtypes based on several properties, such as cell size, shape and density of striations.

\begin{tabular}{|c|c|c|}
\hline Section & Taxon & Collection data \\
\hline \multirow{3}{*}{ Lathyrus } & $\begin{array}{l}\text { L. chloranthus Boiss. } \\
\text { and Balansa }\end{array}$ & B4 Kırşehir: Kaman, Kalehöyük, 1050 m, 3345'578”E -39²0’155”N, 20.06.2010, Çildir 184. \\
\hline & L. sativus $\mathrm{L}$. & A4 Ankara: near Lalahan, 3958’443”N-3307’216”E, 1100 m, 06.05.2009, Çildir 121a. \\
\hline & L. tuberosus $\mathrm{L}$. & 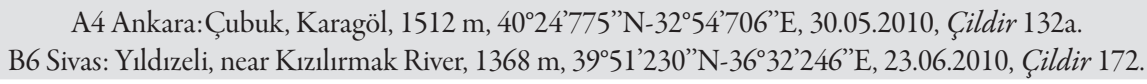 \\
\hline Lathyrostylis & L. digitatus (Bieb.) Fiori & 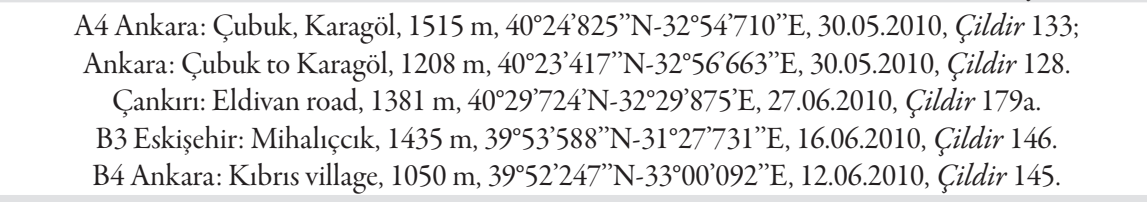 \\
\hline Pratensis & $\begin{array}{l}\text { L. laxiflorus (Desf.) } \\
\text { Kuntze subsp. laxiflorus }\end{array}$ & 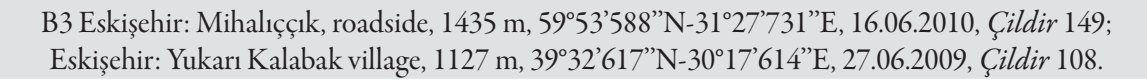 \\
\hline Orobon & $\begin{array}{l}\text { L. roseus Stev. } \\
\text { subsp. roseus }\end{array}$ & 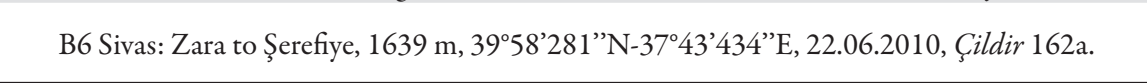 \\
\hline
\end{tabular}

Tab. 2. Distribution of the epidermal types in the dorsal and lateral petals of the taxa examined

\begin{tabular}{cccc}
\hline Section & Taxon & Dorsal petal & Lateral petal \\
\hline \multirow{2}{*}{ Lathyrus } & L. chloranthus & $T R S^{\text {ii }}$ & $T R S^{i i}$ \\
& L. sativus & $T R S^{i}$ & $T R S^{i}$ \\
Lathyrostylis & L.tuberosus & $T R S^{i}$ & $T R S^{i i}$ \\
Pratensis & L. digitatus & $A S^{i}$ & $A S^{i i i}$ \\
Orobon & $\begin{array}{c}\text { L. laxiflorus subsp. } \\
\text { laxiflorus }\end{array}$ & $P C S$ & $T R S^{i i i}$ \\
\hline
\end{tabular}

Subtype TRSi: Elongated cells with dense striations. Observed in the dorsal and lateral petals of $L$. sativus (Fig. 13-14), the dorsal petals of $L$. roseus subsp. roseus (Fig. 9-10) and L. tuberosus (Fig. 15). Subtype TRS ${ }^{\mathrm{ii}}$ : More or less isodiametric cells with dense striations. Observed in the dorsal and lateral petals of $L$. chloranthus (Fig. 1-2) and the lateral petals of L. tuberosus (Fig. 16). Subtype TRS ${ }^{\text {iii: }}$ Elongated cells with less-dense striations. Observed in the lateral petals of L. laxiflorus subsp. laxiflorus (Fig. 7, 8).

Type 2. Areolate cells with more or less striations (AS): This type was further subdivided into three subtypes based 

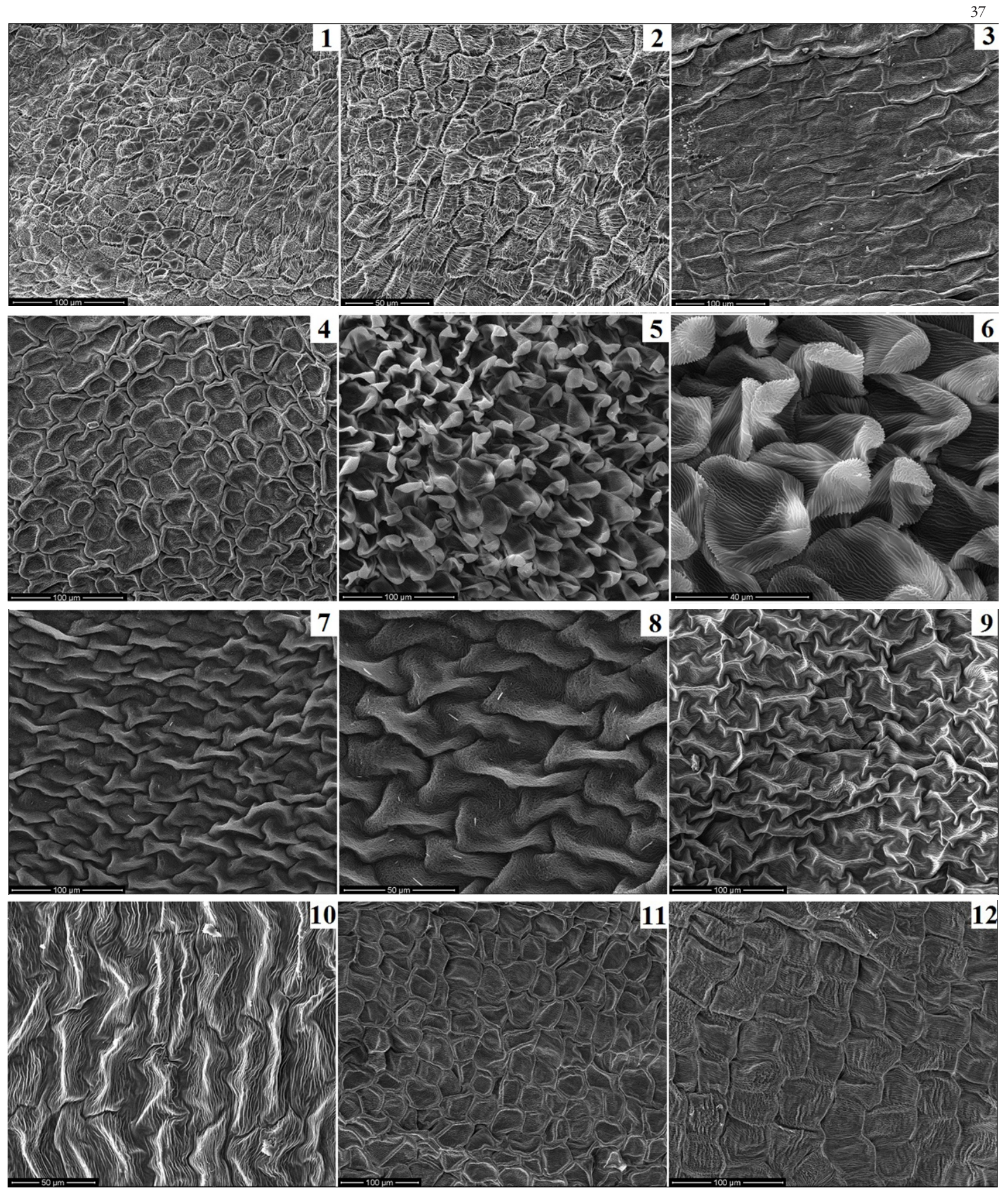

Fig. 1-12. SEM micrographs showing the petal epidermal micromorphology of the Lathyrus taxa studied. Dorsal petals of (1) $L$. chloranthus, (3) L. digitatus, (5, 6) L. laxiflorus subsp. laxiflorus and (9, 10) L. roseus subsp. roseus. Lateral petals of (2) L. chloranthus, (4) L. digitatus, $(7,8)$ L. laxiflorus subsp. laxiflorus and $(11,12)$ L. roseus subsp. roseus

on several properties, such as cell size, shape and waviness of the cell margin.

Subtype AS: Elongated cells with straight anticlinal walls. Observed in the dorsal petals of $L$. digitatus (Fig. 3). Subtype AS ii. Isodiametric cells with straight or weakly curved anticlinal walls. Observed in the lateral petals of L. roseus subsp. roseus (Fig. 11-12). Subtype AS ${ }^{\text {iiii }}$ : Isodiametric cells with curved anticlinal walls. Observed in the lateral petals of $L$. digitatus (Fig. 4). 

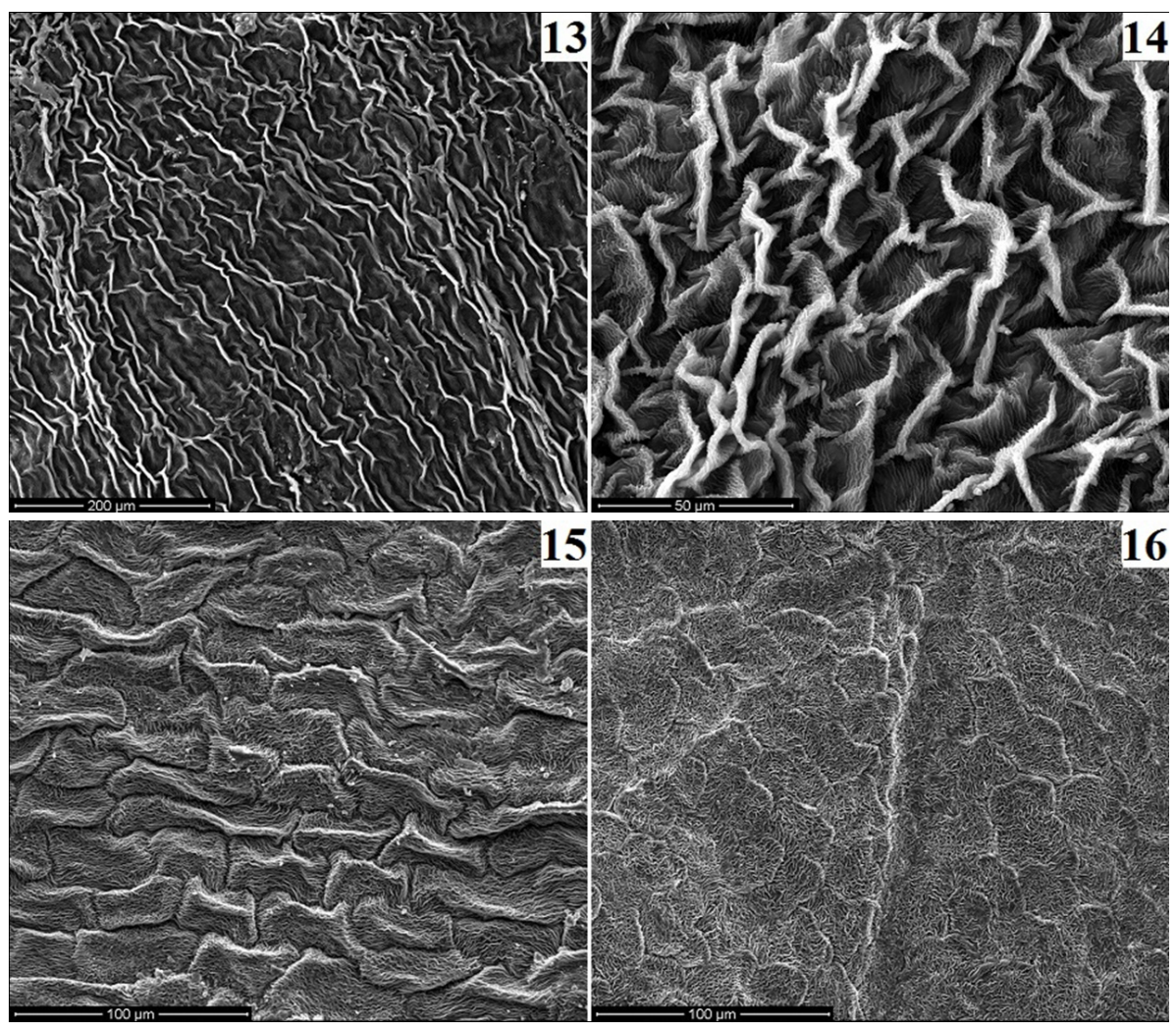

Fig. 13-16. SEM micrographs showing the petal epidermal micromorphology of the Lathyrus taxa studied. Dorsal petals of (13) L. sativus and (15) L. tuberosus. Lateral petals of (14) L. sativus and (16) L. tuberosus

Tab. 3. Distribution of the trichome types and density on sepals of the taxa examined

\begin{tabular}{ccccccc}
\hline \multirow{2}{*}{ Section } & \multirow{2}{*}{ Taxon } & \multirow{2}{*}{ Peltate glandular } & \multicolumn{2}{c}{ Capitate glandular } & \multicolumn{2}{c}{ Nonglandular } \\
\cline { 3 - 7 } & L. chloranthus & Subtype i & Subtype ii & Subtype i & Subtype ii \\
\hline \multirow{2}{*}{ Lathyrus } & L. sativus & - & + & - & \pm & + \\
& L. tuberosus & - & - & + & - & - \\
Lathyrostylis & L. digitatus & - & - & - & - & - \\
Pratensis & L. laxiflorus subsp. laxiflorus & - & - & + & + & - \\
Orobon & L. roseus subsp. roseus & - & - & + & $-/ \pm$ & - \\
\hline
\end{tabular}

$(-)$ absent, $( \pm)$ scarce, $(+)$ present

Type 3. Papillose conical striate cells (PCS): This type was observed only in the dorsal petals of $L$. laxiflorus subsp. laxiflorus (Fig. 5-6).

\section{Sepal micromorphology}

The sepals of the studied taxa had irregular cells with undulated to sinuated anticlinal walls. Three different trichome types on the epidermal cells were observed: peltate, capitate glandular, and nonglandular trichomes (Fig. 17-28, Tab. 3).

The peltate glandular trichomes had a basal epidermal cell, one neck cell and multicellular secretory head. They were found in the grooves of the calyces of $L$. chloranthus (Fig. 17, 18), but absent on those of the others.

The capitate glandular trichomes had a basal epidermal cell, unicellular stalk, a neck cell and a cutinized secretory head. They were subdivided into two subtypes on the basis of their structure: (i) composed of a unicellular globose secretory head. This subtype was found only in $L$. chloranthus (Fig. 17-19). (ii) composed of a multicellular oval sectetory head. This subtype was mainly situated on the sepal teeth of $L$. roseus subsp. roseus and $L$. tuberosus and the sides of the sepal ribs of L. laxiflorus subsp. laxiflorus (Fig. 22-25, 27, 28).

The nonglandular trichomes were subdivided into two subtypes on the basis of their structure: (i) composed of short acicular epidermal cells. This subtype was always present in L. chloranthus and L. laxiflorus subsp. laxiflorus, but very rare or absent in the others; (ii) composed of long filamentous epidermal cells. They were situated on the teeth and ribs of the calyces of $L$. chloranthus and $L$. laxiflorus subsp. laxiflorus (Fig. 17-20, 22). 


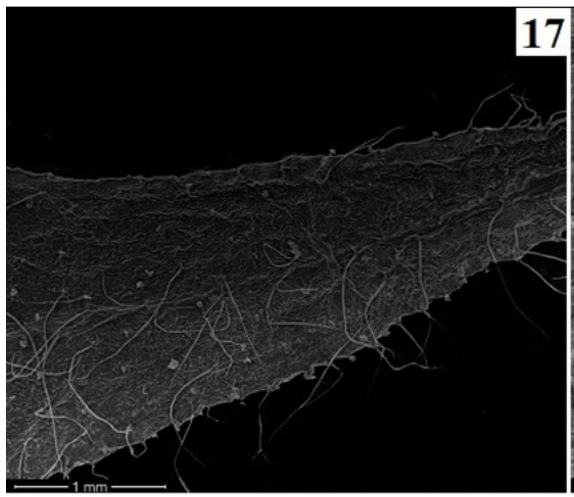

18
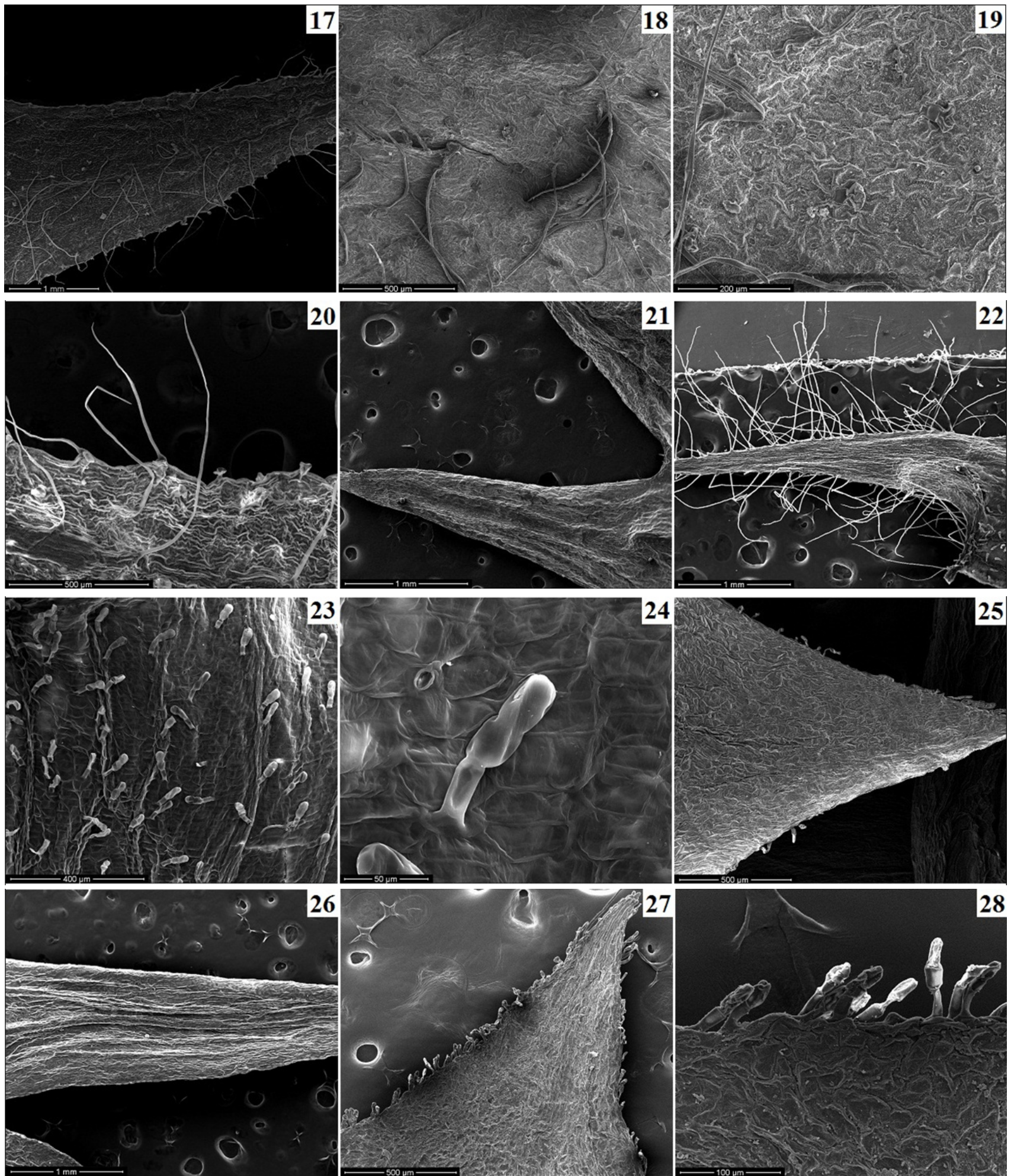

Fig. 17-28. SEM micrographs showing trichomes and epidermal micromorphology of sepals of the Lathyrus taxa studied. (17-20) L. chloranthus, (21) L. digitatus, (22-24) L. laxiflorus subsp. laxiflorus, (25) L. roseus subsp. roseus, (26) L. sativus, and (27-28) L. tuberosus

\section{Discussion}

The micromorphological data play significant role in the modern classification of angiosperms (Heywood, 1971). Petal micromorphology represents an important character in separation of taxa (Metcalfe and Chalk, 1957). Ojeda et al. (2009) analyzed the epidermal types and their distribution within the family Fabaceae and concluded that papilionoids had a high degree of petal micromorphological variation, and great differences between the dorsal, 
40

lateral, and ventral petals occurred, but found only smaller differences among Lathyrus species. TRS was found on the three petal types of some species, such as L. japonicus, L. latifolius, $L$. sativus, and $L$. sylvestris. In L. venatus, the dorsal and lateral petals had papillose knobby rugose cells (PKR), whereas the ventral petals had TRS. In L. vernus, the dorsal and ventral petals had TRS while the lateral petals had PKR. The present study showed that there was micromorphological variation between the dorsal and lateral petals of the taxa. TRS was the dominant epidermal type in the dorsal and lateral petals of the taxa. PCS and AS epidermal types were observed in L. digitatus, L. laxiflorus subsp. laxiflorus, and $L$. roseus subsp. roseus, but PKR was not recognized in any taxa. The dorsal and lateral petals of $L$. chloranthus, $L$. digitatus, $L$. sativus, and $L$. tuberosus had the same major micromorphology. However, this was not the case in L. laxiflorus subsp. laxiflorus with PCS on the dorsal petal and TRS on the lateral petal; and $L$. roseus subsp. roseus with TRS on the dorsal petal and AS on the lateral petal.

L. chloranthus, L. sativus, and L. tuberosus had the same main epidermal type (TRS) on their dorsal and lateral petals, however, minor differences in cell size, shape (isodiametric or elongated), and density of striations allow clear petal micromorphological identification of these taxa. TRS was subdivided into three subtypes: $T R S^{i}, T R S^{i}$ and $T R S^{i i i} . T R S^{i}$ was found on the dorsal and lateral petals of $L$. sativus and the dorsal petals of $L$. tuberosus, but TRS $S^{i}$ was found on the dorsal and lateral petals of $L$. chloranthus and the lateral petals of $L$. tuberosus.

Among the taxa $L$. digitatus and L. roseus subsp. roseus had $A S$ cell type, which was differentiated by cell size, shape (isodiametric or elongated), and waviness of the cell margin. $A S^{i}$ was subdivided into three subtypes: $A S^{i}, A S^{i}$ and $A S^{i i i} . A S^{i}$ was observed on the dorsal petal of $L$. digitatus, $A S^{i i}$ on the lateral petal of $L$. roseus subsp. roseus and $A S^{\text {iii }}$ on the lateral petal of $L$. digitatus.

Molecular genetic studies show that each petal in a papilionoid legume flower has a distinct molecular identity that may be marked by epidermal type (Cronk, 2006; Weng et al., 2011). Many studies have focused on the molecular genetics of PCS cell type. MIXTA, an MYB transcription factor, is responsible for the differentiation of PCS in Anthirrinum majus and in some species of Solanaceae (Glover and Martin, 2002; Noda et al., 1994). However, there is not yet any evidence that MIXTA plays a role in PCS differentiation in legumes (Ojeda et al., 2009). In Lotus japonicus, the genes, CYCLOIDEA 2 (LjCyc2) and KEELED WING 1 (KEW1 or $\mathrm{LjCyc3)}$ are associated with dorsal and lateral petal identity, respectively (Weng et al., 2011). Now, there is no information about the precise pathway by which petal identity genes promote the differentiation of the epidermal types described in this study.

Legumes show a variety of uni- and multicellular trichomes, both secretory and nonsecretory, on the vegetative (Franceschi and Giaquinta, 1983; Retallack and
Willson, 1988; Shaheed and Illoh, 2010) and floral organs (Bernard and Singh, 1969; de Freitas Mansano and de Pádua Teixeira, 2008; Guard, 1931; Gunasinghe et al., 1988; Healy et al., 2005; Lersten and Burubaker, 1987; Tucker, 1997). The present study agrees with the findings of the previous studies conducted on the legumes. Only the calyces of $L$. chloranthus carried peltate glandular trichomes. The capitate glandular and non-glandular trichomes differed in structure. Whereas L. chloranthus had unicellular globose-headed capitate trichomes (capitate subtype i), L. laxiflorus subsp. laxiflorus, L. roseus subsp. roseus, and L. tuberosus had the multicellular oval-headed capitate trichomes (capitate subtype ii). The short acicular (nonglandular subtype i) and long filamentous nonglandular trichomes (nonglandular subtype ii) were always found in L. chloranthus and L. laxiflorus subsp. laxiflorus.

\section{Conclusions}

Little is known of the petal and sepal micromorphology of the genus Lathyrus. Therefore, the present study provides a more extensive knowledge of petal and sepal surface properties of the genus. Lathyrus taxa can be separated on the basis of the petal and sepal micromorphology. Different petals within a flower of Lathyrus can also be separated micromorphologically.

\section{Acknowledgments}

We would like to thank the Directory of Scientific Research Projects (BAP) of the Middle East Technical University, and the Scientific and Technological Research Council of Turkey (TÜBİTAK) for financial support; and the curators of the following herbaria ANK, CUFH, E, GAZI, HUB and KNYA for allowing us to study their Lathyrus collections.

\section{References}

Asmussen C, Liston A (1998). Chloroplast DNA characters, phylogeny and classification of Lathyrus (Fabaceae). Am J Bot 85:387-401.

Baagoe J (1977). Taxonomical applications of ligule microcharacters in Compositae. 1. Anthemideae, Heliantheae and Tageteae. Bot Tidsskr 71:192-223.

Baagoe J (1980). SEM-studies in ligules of Lactuceae (Compositae). Bot Tidsskr 75:199-217.

Barthlott W, Ehler N (1977). Raster-Elektronemmikroskopie der Epidermis-Oberflächen von Spermatophyten. Tropische Subtropische Pflanzenwelt 19:367-467.

Bernard RL, Singh BB (1969). Inheritance of pubescence type in soybeans: glabrous, curly, dense, sparse, and pubescent. Crop Sci 9:192-197.

Chittenden FG (1951). The Royal Horticulural Society Dictionary of Gardening 3:1132-1134. Oxford: Clarendon Press. 
Christensen K, Hansen H (1998). SEM-studies of epidermal patterns of petals in the angiosperms. Opera Bot 135:1-91.

Croft AM, Pang ECK, Taylor PWJ (1999). Molecular analysis of Lathyrus sativus L. (grasspea) and related Lathyrus species. Euphytica 107:167-176.

Cronk QC (2006). Legume flowers bear fruit. Proc of the Nat Acad Sci USA 103:4801-4802.

Czefranova ZV (1971). Review of the species of the genus Lens Mill. Nov Syst PI Vas 8:197-204.

Davis PH (1970). Lathyrus L., vol. 3, 328-369 p. In: Davis $\mathrm{PH}$ (Ed.). Flora of Turkey and the East Aegean Islands. Edinburgh University Press, Edinburgh.

Davis PH, Mill RR, Kit T (1988). Flora of Turkey and East Aegean Islands, vol. 10. Edinburgh University Press, Edinburg.

de Freitas Mansano V, de Pádua Teixeira S (2008). Floral anatomy of the Lecointea clade (Leguminosae, Papilionoideae, Swartzieae sensu lato). Plant Syst Evol 273:201-209.

Doğan M, Kence A, Tigin C (1992). Numerical taxonomic study on Turkish Lathyrus (Leguminosae). Edinb J Bot 49:333-341.

Franceschi VR, Giaquinta RT (1983). Glandular trichomes of soybean leaves: cytological differentiation from initiation to senescence. Bot Gaz 144:175-184.

Genç H, Şahin A (2011). A new species of Lathyrus L. (Fabaceae) from Turkey. J Syst Evol 49(5):505-508.

Glover BJ, Martin C (2002). Evolution of adaptive petal cell morphology. In: Cronk QCB, Bateman RM, Hawkins JA (Eds.) Developmental genetics and plant evolution. London: Taylor and Francis.

Guard AT (1931). Development of floral organs of the soy bean. Bot Gaz 91:97-102.

Gunasinghe UB, Irwin ME, Kampmeir GE (1988). Soybean leaf pubescence affects aphid vector transmission and field spread of soybean mosaic virus. Ann Appl Biol 112:259272.

Güneş F, Özhatay N (2000). Lathyrus L., vol. 11, $92-94$ p. In: Güner A, Özhatay N, Ekim T, Başer KHC (Eds.). Flora of Turkey and the East Aegean Islands, Edinburgh University Press, Edinburgh.

Hammett KRW, Muray BG, Markham KR, Hallet IC (1994). Interspecific hybridization between Lathyrus odoratus and Lathyrus belinensis. Int J Plant Sci 155:763-771.

Hansen HV (1991). Phylogenetic studies in Compositae tribe Mutisieae. Opera Bot 109:1-50.

Healy RA, Horner HT, Bailey TB, Palmer RG (2005). A microscopic study of trichomes on gynoecia of normal and tetraploid Clark cultivars of Glycine max and seven nearisogenic lines. Int J Plant Sci 166:415-425.

Heywood VH (1971). Scanning Electron Microscopy. Systematic and evolutionary applications. London.
ILDIS (2002). International legume database and information service. World database of legumes, version 6.05. Southampton, UK.

ILDIS (2010). International legume database and information service. http://www.ildis.org/

Kahraman A, Celep F, Dogan M (2010). Anatomy, trichome morphology and palynology of Salvia chrysophylla Stapf (Lamiaceae). S Afr J Bot 76:187-195.

Kay QON, Daoud HS, Stirton CH (1981). Pigment distribution, light reflection and cell structure in petals. Bot J Linn Soc 83:57-84.

Kenicer G, Kajita T, Pennington R, Murata J (2005). Systematics and biogeography of Lathyrus (Leguminosae) based on internal transcribed spacer and cpDNA sequence data. Am J Bot 92:1199-1209.

Kupicha FK (1983). The infrageneric structure of Lathyrus. Notes Roy Bot Gard Edinb 41:209-244.

Leht M (2009). Phylogeny of Old World Lathyrus L. (Fabaceae) based on morphological data. Feddes Repert 120(1-2):5974.

Lersten NR, Brubaker CL (1987). Extrafloral nectaries in Leguminosae: review and original observations in Erythrina and Mucuna (Papilionoideae: Phaseoleae). Bull Torrey Bot Club $114(4): 437-447$.

Lewis GM, Schrire B, Mackinder B, Lock M (2005). Legumes of the world. Kew Press, London.

Noda K, Glover BJ, Linstead P, Martin C (1994). Flower colour intensity depends on specialized cell shape controlled by a Myb-related transcription factor. Nature 369:661-664.

Metcalfe CR, Chalk L (1957). Anatomy of the dicotyledons I, 504-516 p. Clarendon Press, Oxford.

Ojeda I, Francisco-Ortega J, Cronk QCB (2009). Evolution of petal epidermal micromorphology in Leguminosae and its use as a marker of petal identity. Ann Bot 104:1099-1110.

Retallack B, Willson JHM (1988). Morphology, anatomy, and distribution of capitate glandular trichomes on selected Trifolium species. Crop Sci 28:677-680.

Senn HA (1938). Expeimental data for the revision of the genus Lathyrus Linn. Am J Bot 25:67-78.

Shaheed SA, Illoh HC (2010). A taxonomic study of some species in Cassiinae (Leguminosae) using leaf epidermal characters. Not Bot Horti Agrobo Cluj 38(1):21-27.

Stirton CH (1981). Petal sculpturing in papilionoid legumes. In: Polhil RM, Raven PH (Eds.) Advances in legume systematics. London: HSMO.

Tucker SC (1997). Floral evolution, development, and convergence: the hierarchical-significance hypothesis. Int J Pl Sci 158:143-161.

Weng L, Tian Z, Feng X, Li X, Xu S, Hu X, Luo D, Yang J (2011). Petal Development in Lotus japonicus. J Integr Plant Biol 53(10):770-782. 